\title{
Marketing's theoretical and conceptual value proposition: opportunities to address marketing's influence
}

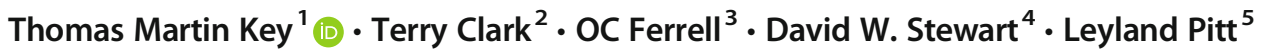

Received: 3 October 2019 / Accepted: 4 June 2020 / Published online: 27 July 2020

(C) Academy of Marketing Science 2020

\begin{abstract}
This paper is composed of scholarly essays that explore the problematic nature of marketing's influence within the academy and organizations, potential explanations and causes, and how conceptual and theoretical research can address and move our discipline forward. Each section represents material and research developed through interactive sessions from Academy of Marketing Science conferences. Topics include the history of the marketing discipline, its innovation and loss of domain expertise; important internal and external environmental concepts that have impeded relevance and theoretical impact; foundational elements of how the discipline frames problems, provides methodological-based solutions, and influences the very subjects of our research in such a way as to lesson our contribution to scholarship and practice; and finally the discipline's inability to understand the intangible nature of marketing activities and outcomes, as well as marketers' struggle to articulate relevance in a way that is easily understood in the language of finance. Through this critical self-examination of the field of marketing a central premise emerged — a discipline-wide drift and myopic approach to rigor and relevance.
\end{abstract}

Keywords Conceptual and theoretical research $\cdot$ Marketing influence $\cdot$ Discipline drift $\cdot$ Discipline myopia

“...the marketing discipline faces an urgent need for a rethinking of its fundamental purpose, premises, and implicit models that have defined marketing for at least the past 50 years" (Webster and Lusch 2013, p. 389).

"...the increase in [marketing] knowledge [presently] occurs at a decreasing rate, and marketing knowledge has reached a stage of maturity.... The more mature a research field, the less groundbreaking its new findings, which therefore leads to less increase in knowledge..." (Eisend 2015, p. 37).

Thomas Martin Key

tkey@uccs.edu

Terry Clark

tclark@cba.siu.edu

OC Ferrell

ocf0003@auburn.edu

David W. Stewart

david.stewart@1mu.edu

Leyland Pitt

lpitt@sfu.ca
The discipline of marketing has made great strides in developing and testing models related to markets, brands, channels, and customer behavior. However, the discipline's continued relevance and academic value proposition founded on theoretical and conceptual research is more important than ever as marketing managers (and scholars) face unprecedented marketplace and technological disruption (Moorman et al. 2019). This is evident in how quickly new business models, advances in mobile technology, digital marketing channels, and customer preferences have changed around the planet (Gatignon et al. 2017; Key 2017). Indeed, the COVID-19 pandemic of 2020

1 Department of Marketing, Strategy, and International Business, College of Business and Administration, University of Colorado, Colorado Springs, Colorado Springs, CO 80918, USA

2 Department of Marketing, College of Business, Southern Illinois University, Carbondale, IL 62901, USA

3 Department of Marketing, Raymond J. Harbert College of Business, Auburn University, Auburn, AL 36849, USA

4 Department of Marketing and Business Law, College of Business Administration, Loyola Marymount University, Los Angeles, CA 90045, USA

5 Department of Marketing, Beedie School of Business, Simon Fraser University, 500 Granville Street, Vancouver BC V6C 1W6, Canada 
illustrates the necessity of new theoretical value creation in areas such as digital marketing and the strategic value of supply chains. Moreover, the pandemic has revealed that what is needed does not consist of demand stimulation but equitable distribution. It is through theoretical development that scholars make sense of these complex issues and create frameworks necessary to parsimoniously describe, explain, and predict. Many disciplines, and scientific knowledge as a whole, tends to have a "half-life" through which contributions decay as the dynamic nature of external environments continue to evolve (Varadarajan 2017). Lack of properly guided relevant and new-to-the discipline theory development has created concern in some scholars over marketing's declining influence in research that impacts our discipline and practice (e.g., Yadav 2010, 2018, 2020; Clark et al. 2014).

Discipline critiques, however, are often lost among the majority. While Homburg et al. (2015) and Homburg et al. (1999) show the influence of marketing departments declining over the past two decades, Gupta et al. (2004) and Kumar and Shah (2009) suggest the marketing function actually contributes to shareholder value. While Nath and Mahajan (2008) suggest that marketing has little effect on firm performance, Feng et al. (2015) argue that marketing's influence is increasing and is a key driver of firm performance. Another aspect of this controversy is revealed by Clark et al.'s (2014) recent bibliometric analysis of top accounting, finance, management, and marketing journals that clearly reveals marketing scholarship is by far the least influential among all of the business disciplines.

Clark et al. (2014) confirm that a possible explanation for marketing's lack of influence is that while theoretical and conceptual articles are the most highly cited in the field, the production of such articles has declined (Yadav 2010; see Hunt 2018 for an updated review of theory article impact). Yadav (2010) adds that while conceptual work in marketing tends to win the most best paper awards and is highly cited, the number of such papers appearing in premier marketing journals has declined significantly. The combination of inconclusive empirical evidence for marketing department power within the firm and the discipline's lack of impact among other business disciplines begs a number of questions: do marketing scholars ask and pursue the right issues? Do they interface with appropriate business functions? Are they creating a relevant knowledge base for the twenty-first century? (Webster and Lusch 2013; Eisend 2015; Ferrell 2018; MacInnis et al. 2020). Hunt (2018) explores the development of our discipline throughout its various eras and his prognosis for the future of marketing scholarship is that we will be dependent on a new generation of scholars pushing the discipline forward in the area of strategic marketing research specifically in the form of theoretical and conceptual work. In fact, many journals have called for an increase in theoretical and conceptual research despite the decreasing number of papers that are currently published (see Moorman et al. 2019 for a summary of conceptual article decline).

This paper represents a dissenting perspective on the current course of scholarship in marketing. It does so by bringing together the highlights of ongoing conversations among a group of five scholars who articulate various concerns regarding the state and trajectory of the field combined with the need to apply theoretical and conceptual work to move our discipline forward, increase impact, create value, and preserve our overall relevance. It is critical to note that the purpose of these dissenting opinions is not to cast a disparaging shadow on the incredible work marketing scholars have produced over the last several decades, rather to stimulate critical self-reflection at the discipline level in order to combat an uninformed march into an unintentional future that results in lack of relevancy. It is our intention to shed light on the enormous opportunity marketing researchers have to create valuable knowledge for dissemination in our academic journals that impact our classrooms and the boardroom. This can be accomplished if we are willing to question our current course as a relevant business discipline and look critically at how we got to our current state, not all of which is bad, but which nevertheless needs revisiting in order that we bring to fruition the full potential of our value proposition as a discipline.

These essays emerged across numerous special sessions held at the Academy of Marketing Science conference between 2014 and 2019. Herein, the authors purposefully selected topics that challenge the status quo of our discipline and find faults with the intent to bring conversations about the state-of-our art to the surface. The focus is a deep dive into the legacy gaps of our research heritage, rather than offer complete answers. Accordingly, there is occasional hyperbolic intent within some of these scholarly essays meant to reveal blind spots and intellectual apathy, taken-for-granted familiarity of research style, methodology, and delivery. The various themes that emerged in relation to marketing's relevance and influence rightly triggered heated debate, agreement, and push-back. It is our hope that the fruit of six years of passionate exploration will provide insight into the structure of our field. Certainly, a substantial (albeit minority) number of scholars have been calling for a reexamination of marketing and its place inside the firm and in the world (e.g. Webster and Lusch 2013).

The collection begins with OC Ferrell's critique of how marketing lost its way with innovation in supply chain management (120 years before Amazon), an area seemingly lost to the field. This look at areas the marketing discipline once "owned" is a pertinent reminder of the changes that an entire discipline can undergo and the extent to which atrophy and discipline-drift can occur. It is also a call to action to protect our expertise in substantive domains before they become eroded, especially without significant theoretical and conceptual development that anchors our knowledge base and 
informs empirical investigation. Next, Leyland Pitt looks at the legacy of how marketing ignores key internal and external environmental concepts, slowing the theoretical, conceptual, and practical impact of the field. This perspective opens the door for cross-discipline collaboration in areas such as marketing and biology. Following that, Terry Clark argues that three related factors push marketing into further marginalization. They combine to simultaneously drive marketing scholarship deeper into marginalization and describe the perfect environment for theorizing difficult-to-understand and sophisticated market-related problems. Finally, David Stewart addresses how a perception problem, stemming from an incomplete understanding of how the field engages with some of marketing's intangibility issues, makes it difficult to communicate marketing's financial value to the firm.

\section{Evaluating the current status of the marketing discipline}

\section{OC Ferrell}

To understand marketing today, it is important to evaluate the development of the discipline (Ferrell 2018; Bagozzi 2018; Kotler 2018; El-Ansary et al. 2017). While there is controversy on the narrow behavioral and quantitative direction of marketing today, there is general agreement that marketing should be managerially relevant to organizations (Kumar 2015). Both marketing practice and academic research appear to have constituencies questioning how the discipline is contributing to organizational success (Houston 2016). Is marketing contributing to advancing marketing strategy? Does marketing have a theoretical foundation to support contributions to knowledge through meaningful research? Is the marketing discipline contributing enough to societal issues? McAlister (2016) suggests that academic marketers are becoming methodologists.

This is a concise examination of the current status of the marketing discipline. It is limited in scope but identifies some challenging issues. Many marketing scholars are making important contributions to theory development, research, and marketing practice. Marketing should be inclusive and encourage diversity in theory and research for managerial, societal, and public policy domains. If the marketing discipline becomes too narrow, focusing on minor problems, the relevance of the discipline diminishes. Steenkamp (2018) suggests we are moving away from synergy and creating a balkanization of research as well as marketing departments. My position is to point out that marketing has narrowed its scope and needs to broaden its contribution to understanding the marketing system. I am optimistic that we, as a discipline, will improve and broaden our interests in creating knowledge to address marketing problems. My concern is that marketing has narrowed its scope to mainly focus on demand stimulation with limited focus on the interrelationships in the marketing system. Steenkamp (2018) suggests research is needed that is academically rigorous but managerially relevant.

It is important to examine the history of marketing to benchmark the current situation. The academic discipline of marketing is about 120 years old, but marketing has been successfully practiced for hundreds of years. Tracing the development of technology provides an understanding of advances in marketing. Developments in transportation such as railroads, urbanization, and communication systems help to create a marketing environment to advance our institutions and supply chain networks. The theory of economic utility gave manufacturing credit for creating value for buyers because raw materials were transformed into products. But marketing emerged to create value through time, place, and possession utilities (Tamilia et al. 2020). Marketing has always been important in supporting an economic system to provide a standard of living for consumers. Marketing has created distribution and communication systems to advance interorganizational relationships and consumer satisfaction.

\section{Brief historical overview}

In order to understand the academic field of marketing today, it is important to examine the historical roots of marketing practice and the development of scholarship. Marketing thought and practice has advanced but most doctoral programs no longer teach the history of marketing and marketing theory courses. Marketing was not just discovered in the last 60 years, and marketers have always been innovative. Examining our history indicates great diversity in the discipline's contributions to all parts of the marketing system.

For example, in the 1860 s, department stores emerged as a new marketing innovation. Department stores were just as innovative as Amazon is today. They provided an assortment of diverse products in one location and created an atmosphere of interest and excitement for customers. A.T. Stewart developed the first department store in New York and also went into wholesaling above the department store. He created home delivery and built trolleys to bring customers to the store. The store became an attraction with customers traveling long distances to shop. Marketing has always been innovative and customer-focused, building new business models and institutions.

Some claim the marketing concept was created in the $1950 \mathrm{~s}$, but it was really alive in the $1800 \mathrm{~s}$. In this same period, Montgomery Ward took advantage of railroads to deliver products and created catalog retailing. People on farms in distant areas could get everything they needed. Sears published its first complete catalog in 1893, and it expanded to more than 500 pages in 1895 . Sears did not have a retail store for more than 30 years after the first catalog. They sold almost any product customers wanted, including cars and houses. 
People had to go to the train station to pick up products in the early years, but they had access to new products that were not locally available. In a way, Sears was like Amazon without the transportation and communication systems we have today. These pioneers were as innovative and creative as people who are working with digital marketing today. They understood customer satisfaction and how to build a marketing system with no computers. Sears' fulfillment center in Chicago handled 300,000 to 400,000 orders a day in the early 1900 s (Tamilia et al. 2020).

The conceptual and theoretical development of marketing continues to be important in guiding research and knowledge development. Throughout the past 120 years, academic marketing theories have been important. The conceptual and theoretical foundation of marketing evolved from economics. In fact, early scholars used economic theory to launch the discipline of marketing, and it was considered applied economics (Ferrell et al. 2015). As early as 1912, marketing was positioned as two major tasks: a demand creation task (demand stimulation) and a supply management task that moved products and made them available to customers (Shaw 1912). As marketing evolved, Cox (1961) predicted it would need more research in sociology, psychology, anthropology, and statistics.

Alderson made a major contribution to expanding the conceptual foundation of marketing. Alderson developed the marketing theory of functionalism, which is similar to the economic theory of monopolistic competition. He viewed marketing as supply and demand but had a dynamic view of relationships in the organization (Alderson 1957). While marketing has always had scholars that developed conceptual frameworks and theory, the interest has diminished as behavioral theories and methodological sophistication became the driving force in research (McAlister 2016). Marketing has focused more on importing theory from the behavioral sciences. This failure to develop marketing theories could diminish the impact of the discipline on important components of the marketing system. Methodological rigor and consumer data availability have resulted in less concern about theory and the entire marketing system (Kumar 2015).

There has been progress in the marketing discipline developing theories. Shelby Hunt's books and articles have been used in many doctoral courses to help understand and relate theory to empirical research (Hunt 1991). In addition, Hunt's resource advantage theory provides a theory of competition that includes both supply and demand considerations that could be applied to any area of marketing (Hunt 1991). Hunt (2020) states that marketing imports its theories and concepts almost exclusively from other disciplines. Marketing has not developed indigenous marketing theory as a foundation for empirical research because of a failure for foundational procedures and approaches for developing marketing theory. Hunt (2020) goes on to use service-dominant logic (S-D logic) as an approach to develop marketing theory based on an inductive realist approach. The failure to teach marketing theory courses in doctoral programs perpetuates the use of imported theory in research. More marketing theory development is being supported by the initiatives and articles in AMS Review.

Vargo and Lusch (2008) provided a conceptual framework for S-D logic, that has a wide-spread impact on marketing theory. Based on S-D logic, service is reconceptualized as a process of actors using their resources (e.g., knowledge and skills) for others' benefit and sees it as the basis for all of exchange, including that which provides service indirectly, through goods. S-D logic has progressed considerably beyond this foundational reconceptualization and has become a more holistic orientation for understanding value (co)creation in service ecosystems, coordinated by institutional arrangements (Vargo and Lusch 2016). This service ecosystems orientation is sufficiently broad to capture and elaborate "supply" and "supply-chain" phenomena and integrate them with "demand" and "demand-chain" phenomena, for a combined understanding. Despite these examples of exceptions, more work is needed.

\section{The marketing discipline drifts}

Marketing should be an integrated system that considers supply (supply chain management) and demand (persuasion) as equally important. Howard (1983) addressed this issue in his "Marketing Theory of the Firm." He started by focusing on the need to be customer-driven. His theory provides a rationale for planning an integration strategy with other functions in the design and implementation of strategy. This would be integrating supply and demand.

Marketing as a discipline has drifted away from its early pioneers. We focus on narrow problems with a very sophisticated methodology. It has become very easy to get data (e.g., Mechanical Turk, Qualtrics, and student samples). Dataset Search has indexed almost 25 million data sets providing a one stop shop. Experiments on minor problems that may have limited interest to practitioners are conducted using the very latest methods and imported theories. One of the reasons research focuses on the customer and neglects the complete marketing system is due to the ease of consumer research (Kumar 2015). It can be challenging to do research related to interorganizational relationships found in business-to-business, marketing channels, and supply chain networks. This research often requires firm data that is harder to acquire and rarely online.

Marketing has not focused on the strategic importance of supply chains, especially during disasters. The 2020 COVID19 pandemic placed the supply chain as the most visible marketing element to sustain a lifestyle and maintain personal health. First, the health system found shortages of personal protection equipment, and there were many conflicts about 
where supplies would be distributed. Some products became scarce at supermarkets and farmers had to plow under crops due to disruption in demand patterns. Market channels changed abruptly as online retail became more important and food consumption patterns changed due to working from home and less dining out. More is needed to be known about supply chain depth, procurement alternatives, and logistics management. The need for supply assurance to meet customer needs made supply chain much more visible to the mass media and customers.

There has been a division of the supply side and demand side of marketing. Academically, marketing and supply chain management have different conferences and journals and seek answers to different research questions (Tamilia et al. 2020). Supply chain management solves practical business problems with a cost-effective customer focus, which is on integrating procurement, logistics, and operations to deliver products as a part of the marketing strategy. Supply chain integrates the various functions of the marketing system. Meanwhile, marketing is preoccupied with obtaining sales (demand) by focusing on the psychological behavior of customers (Tamilia et al. 2020). This is important research, but our discipline could be strengthened and more relevant with diversity in the problems addressed. Marketing has been reduced to more of an influence and persuasion technology, mainly subservient to the needs of the entire marketing system that makes the function complete. Robust issues related to integrating strategic decisions associated with operations, procurement, and logistics now fall outside of marketing. On the other hand, as online retailing advances, so do the big issues that relate to an efficient and effective supply chain. This is of strategic importance, and demand stimulation is more of a tactical area (Tamilia et al. 2020).

Marketing channels and supply networks could benefit from systems thinking that integrates supply and demand. Theory of markets for real-world understanding that corresponds to dramatic changes disrupting traditional marketing channels is needed to advance knowledge. A systems approach could overcome static perspectives and focus on fragmented development that results in silos of knowledge. The philosophy of systems theory is that focus should shift from the parts to the whole and from situations to a web of relationships. All marketing activities should be viewed as a complex system (whole) that is emerging and changing, that cannot be understood by studying the parts in isolation (Vargo et al. 2017). The focus on demand stimulation and supply chain as independent functions does not provide a holistic understanding of marketing as a system of suppliers, buyers, and sellers (Tamilia et al. 2020).

Whether we have grounded theories or just assumptions about the nature of reality, it will influence our view of marketing, customers, and the marketing systems (Tadajewski 2014). In the absence of a general theory of marketing, the discipline has developed a narrow focus on the customer. Our advancement requires organic theories as well as refining and extending theories from other disciplines (Varadarajan 2020). Just as important is discarding flawed theories. Marketing does not have much academic impact across disciplines (Clark et al. 2014). Therefore, marketing could also develop organic theories to assist in understanding phenomena that relate to research in other disciplines (Varadarajan 2020). If marketing is to contribute original theoretical contributions, there needs to be a definition of what constitutes new organic theory. This contribution should be based on existing theoretical discussions. It should include a critique of existing theories that try to explain phenomena (Barney 2020). Finally, we need to consider managerial relevance in an applied discipline such as marketing (MacInnis et al. 2020).

\section{Concluding thoughts}

The marketing discipline needs to address important concerns about theory and conceptual frameworks that drive academic research. Unfortunately, doctoral programs mainly have marketing content and theory to focus on behavioral issues. Many doctoral programs exist with almost all courses focused on methodology. Some programs have no courses on marketing strategy or how marketing should address societal issues. Yadav (2020) states that doctoral programs should place theory at the heart of their curriculum. He points out this is not happening, and we need to reimagine the content and structure of marketing doctoral programs. In other words, put marketing back into marketing doctoral programs.

On the other hand, some marketing scholars address important issues in areas such as strategy, sales, retailing, ethics, and social responsibility. We need leadership from top marketing journals and societies to encourage more research in areas that have been neglected. AMS Review has become the premier marketing journal that focuses exclusively on conceptual and theoretical contributions across all sub-discipline areas in the field of marketing. The Academy of Marketing Science conducts the AMS Review Theory Forum that brings leading and emerging scholars to share their perspectives on marketing theory at their annual conference. The American Marketing Association has conducted pre-conference workshops and special sessions on marketing theory. These are encouraging developments. The discipline will advance as communities of scholars focus on substantive issues that not only interest them but also have an important impact on advancing a body of knowledge related to understanding the entire marketing system. Marketing should welcome and be accommodative to much diversity in research including managerial, societal, public policy, and customer welfare relevance.

Most disciplines evolve and make contributions by creating knowledge useful to society. I believe the marketing discipline will adjust and become more balanced in the problems 
it addresses. To accomplish this, we need strong academic leadership supporting diversity in publishing.

Ferrell's sweeping historical survey provides a fitting backdrop to approach the issue of marketing's declining relevance and the potential for increased theoretical and conceptual problem-solving. This decline is not the work of a moment, but the result of a decades-long drift, a narrowing and impoverishment of the field. Paradoxically, inside the shrinking bubble of our marketing world, an illusion of normalcy prevails. His prescription for a deliberate broadening of the field (again) is aimed at fundamental policy-based changes by journal editors and Ph.D. program Directors. Moving still closer to the act of research in the marketing discipline, Ferrell's diagnosis suggests a disciplinary myopia. Central to a discipline-wide shift is the notion of what relevant questions should be explored and how relevance can be nurtured and protected. One answer is research that studies emerging phenomena (Yadav 2018). This requires making not easily understood or investigated problems a priority that can fuel innovative intellectual contribution that results in marketing's theoretical relevance for issues that matter to business. This could combine research in both existing marketing domains that have been seemingly lost and areas not yet thought relevant. The next essay explores this notion in more detail and pushes the boundaries of traditional marketing research inquiry and scope.

\section{Academic marketing gets ignored...Because academic marketing ignores important things}

\section{Leyland Pitt}

The job of a Chief Marketing Officer (CMO) is a perilous one. Research by Whitler and Morgan (2017) indicated that the average job tenure of a CMO is a lot shorter than for their counterparts in the c-suite, and far briefer than that of the average CEO. This is mostly due to conflict between CEOs and CMOs. $80 \%$ of CEOs don't trust or are not impressed by their CMOs. And it's not just marketing practitioners who tend to be overlooked.

Their academic colleagues aren't faring much better. In an award-winning paper published in Clark et al. 2014, after an extensive exploration of business journals citations, lament, “....opinion and evidence suggest that academic marketing is the least influential of the mainstream academic business disciplines" (p. 223). Marketing as a practice, despite its visibility, gets ignored by other business practitioners; marketing, as an academic discipline, gets ignored by other business disciplines. As a marketing scholar, I contend that marketing gets ignored, because it ignores many important and interesting things that really matter.

As Clark et al. (2014) demonstrate, academic marketing is as advanced as its other business counterparts in using the latest methods and is as rigorous as any. At the same time however, much of academic marketing research seems to prize rigor and truth above all else; whether it is actually interesting or relevant seems to matter less and less. Tellis (2017) points out,

"Most researchers assume that research is a quest for the truth. So, the discovery of truth would automatically be impactful. However, research is impactful not if it is true, but if it refutes the assumption of its audience. Refuting the assumption of the audience is also what makes it interesting. (p. 1)".

To this end, we do not encourage a lack of truth finding, rather, as Hunt (2018, p. 43) points out, our discipline has a significant amount of research that is, "best suited for nonstrategic, micro-level topics that are unlikely to be influential either within marketing or outside its boundaries." In this brief piece, I identify six things that marketing scholarship shouldn't, but does, ignore.

\section{Marketing ignores artifacts and technologies as shapers}

Academic marketing has long been driven by the marketing concept, which holds that in order to reach their objectives organizations need to identify customer needs and satisfy them with appropriate products/services. In this view, offerings are instrumental - there is a human need, and humans create the product/service that will satisfy that need. Unfortunately, this perspective ignores the fact that in many instances, artifacts and technologies shape, and in a sense "create" customers. Many marketing academics would eschew this as a "product orientation," yet the reality is that artifacts and technologies have shaped much of human life. The agricultural revolution has been called history's biggest fraud by writers such as Jared Diamond $(2002,2010)$ and Yuval Harari (2014). They argue that it was not early humans who domesticated plants such as wheat and rice to satisfy their needs, but rather these plants domesticated humans, changing them from healthy hunter-gatherers who hunted lean game animals and foraged for fruit and berries, into more sedentary crop tenders. These plants demanded endless hours of labor and care and were/are not even very healthy or nutritious. By focusing on articulated customer needs and passive instrumentality, marketers ignore shaper offerings. Creative marketers such as Cirque de Soleil's Guy Laliberte, renowned chef Ferran Adria of el Bulli fame, and of course the late Steve Jobs have all espoused a philosophy of disregarding customers who really don't know what they want or need. Berthon et al. (1999) have argued for the need for firms to understand their own stances toward customers and innovation, and that a firm's focus on customers, or on innovative offerings, or on neither, or on both, are contingent, and that 
mode of focus can shift or change over time. Academic marketing still tends to ignore the fact that offerings shape customers.

\section{Marketing ignores biology}

In order to identify better ways of targeting customers and serving them, marketing studies human behavior carefully and intensely. Mirroring the clinical psychology of the 1970s that postulated, for example, that schizophrenia was caused by a child's relationship with its austere, unaffectionate mother, it ignores entirely the fact that much of human behavior has its origins in biology. Today there is strong evidence that many mental diseases are caused not by random chance or ineffectual family relationships, but by protozoan, bacterial or viral infections (Washington 2015). There is robust verification that much of the behavior that marketers are interested in, such as shopping habits, promiscuity, materialism, neuroticism, narcissism, and various personality trait are linked to protozoan infections that alter the brain (Moalem 2007). My colleagues and I attempted to publish a paper on the potential effects of Toxoplasma Gondii, a protozoan that is transmitted through cat feces (thus easily transferred to humans) on various broad level aspects of customer behavior. It wasn't entertained for acceptance at conferences, let alone any marketing journals. That might have simply been because it wasn't a very good paper. But that wasn't the reason reviewers gave for rejecting it: their broad conclusion was that the paper had nothing to do with marketing. We felt somewhat vindicated when a paper appeared in a prestigious management journal a short time later, calling the bug a "puppet master," and elucidating its effects on the behavior of both managers and employees (Houdek 2017). If this bug affects the behavior of managers and workers, then it is certain that it affects the behavior of consumers as well.

Wroe Alderson (1937) was perhaps the first and one of only a few marketers to reference biology in his article on competition. It will be interesting to see whether the COVID-19 pandemic of 2020 will also make its way into marketing research. Given the complete global shutdown that ensued, perhaps marketers will find research interfaces with biologists a salient pursuit. One wonders what insights may have been possible with the potential of over 80 years of development that could have occurred since Alderson.

\section{Marketing ignores information technology...until it's too late}

Marketing scholars tend to ignore new technologies, and this is particularly true of new information technologies, until it's too late to claim them for its own. Although there have been some recent corrections in this regard [see calls for papers from Journal of Marketing (2018); Journal of the Academy of Marketing Science (2020)] they seem to be relatively new. Marketing ignored the Internet in its early days and went on to ignore smart phones. Most of the early work on the commerce of ubiquitous networks (Watson et al. 2002), with a few rare exceptions, was published in MIS journals. In this, marketing scholars lost significant aspects of e-commerce and pricing to MIS scholars, and supply chain management to operations management. Opportunities are ripe for marketing scholars to pay increased attention to wearable devices, augmentedand virtual reality, dynamic pricing, and artificial intelligence.

\section{Marketing ignores its own shadow}

With a few notable exceptions, academic marketing tends to ignore its own shadow. Most academic marketing research and theoretical conceptualization focuses on the "nice," "good," ethical side of marketing: delivering great customer service, positive organizational performance, service dominant logic, and so forth. Much less attention is given to the fact that marketing is very often a coercive, manipulative discipline, one whose sole purpose to many is to "engineer consumption" or to make consumption occur even when it might not have (Sheldon and Arens 1976). Marketing scholars have to face up to the fact that it is also forcible and scheming, and that it gets people to think, believe, and act in ways that are in a firm's, or manager's, best interests - not necessarily those of the customer. Alter (2017) relates the intriguing history of well-known technology CEOs that dramatically limited or completely denied their own children from using the very technology those CEOs developed years before it was common knowledge that too much "screen time" was detrimental to mental health (Berthon et al. 2019). Indeed, marketing can be said to be about turning citizens into consumers, and the real meaning of "consumer(s)" does not make it a nice word. In sixteenth century England, a "consumer" was someone who squanders or wastes, with its origins in the Latin consumere, "to take, to use up, to waste." The verb "consume" means to "destroy, corrode, burn up, reduce to ashes;" the noun "consumption" refers to the "act of consuming, as by use, decay, or destruction." That the archaic term for the disease tuberculosis was "consumption," does not seem accidental: it is described as a "wasting away of the body, particularly from pulmonary tuberculosis."

\section{Marketing ignores new ideas}

For an organizational function at whose heart creativity and innovation lie, academic marketing tends to be the most conservative of business disciplines. It increasingly focuses on rigor at the expense of relevance, on old ideas rather than new with, for example, a seemingly endless revisiting of issues such as trust and commitment, capabilities, and export performance. These may be important, but new ideas and new developments are arguably far more so. Very little recent work 
demonstrates the fresh research approaches possible or exemplifies the opportunities at hand. For example, Taillard, Peters, and Mele (2016) develop a framework that captures how service ecosystems emerge through shared intentions. The authors bring together theories from outside the marketing discipline to help explain and extend current S-D logic in a new and innovative way. In this same vain, work by Rand et al. (2018) provide systematic approaches for capturing emergent marketing phenomena through complex systems analysis. This represents innovative methodologies to explore new ideas and capture, “... key 'initial conditions' that may hold important clues about underlying causal mechanisms" (Yadav 2018, p. 362).

\section{Academic marketing is ignoring good writing}

Sadly, marketing academics today seem to care less about writing well and in a way that is accessible to all relevant stakeholders such as, academics in other fields, business practitioners, the media, and policy makers (MacInnis et al. 2020). A simple comparison of the quality and transparency of the writing in major marketing journals between articles written twenty to forty years ago with those written today really makes this point. I am purposely not citing the sources of the excellent excerpts below in order not to praise the blessed, and refrain from shaming the guilty by not citing their work, but I believe the prose makes the point:

From a paper in JAMS in 1997:

"If MBA degrees came with warranties of perpetual relevance, the decade of the 1990's would present many with grounds for tuition refunds. The ferment in the field of marketing in particular is unprecedented, and it is not difficult to argue (as indeed I shall) that the rate of intellectual capital depreciation in marketing today exceeds that at any time in this century, including the decade in which televisions were introduced." (p....).

And from a paper in JCR in 1992:

"Marketers often refer to a market offering as a product, but a product is merely the frozen potential for performance. Customers may be said to choose products, but they consume performances."

One also wonders whether academic marketers care about the readability, not just grammatical correctness or proficiency in English, of the papers they write - editors certainly do (e.g., Kohli 2009; Frazier 2011; Kumar et al. 2018). This despite work by Sawyer et al. (2008) that found that award-winning articles in elite marketing journals are more readable, as measured by indices such as Gunning's FOG index and Flesch indicators, than non-winning articles. Readability scores are usually reported in terms of the number of years of education a person would need to understand a piece of text; the New York Times for example, has a mean readability score of 7 , which means that a reader who has completed primary school would be able to understand it. Sawyer et al. (2008) most readable papers in major marketing journals had readability levels of around 12; they could be understood by someone who had completed high school. The least readable paper scored 21.3! This is not "good" and doesn't mean that the paper was only written for very welleducated people; it simply means that it wasn't well written. We all prefer to read work that is easy to read, regardless of our level of education or intellectual ability. Indeed, straightforward and comprehensible writing styles combined with interesting and relevant research questions breaks down the boundary between academic pursuit and broader public interest, access, and overall impact (MacInnis et al. 2020).

\section{Concluding thoughts}

There are many previously articulated reasons for the dearth of conceptual work in marketing. Many doctoral programs no longer include a theory component in course work; doctoral students are encouraged to go on the job market with a paper(s) in hand and empirical papers take less time to go through the review process; likewise, once on a tenure track, new $\mathrm{PhDs}$ prefer the greater certainty of the eventual acceptance of empirical work than the risky improbability of the acknowledgment of a theoretical contribution. Yet, it is conceptual work that really drives disciplines forward; think Nash, think Coase, to name a few, let alone Einstein.

Empirical work in marketing languishes in comfortable paradigms: tried and trusted ideas rather than sometimes crazy, but inevitably exciting, new ones (Yadav 2018). Conceptual work also requires better writing, and to many marketing academics this might be the major stumbling block. It is far easier to write up the results of a complex structural equation model than it is to formulate a new theory or conceptualize an interesting new problem.

Pitt's inventory of Marketing myopias is a function of the long-term drift and narrowing of the field argued by the first essay. Taken together, these myopias form the horizons for what the field believes possible and doable: what we feel is "ours" and what belongs to other disciplines. It is important to note however, that this discipline myopia is not in the state of nature, but rather in the perspectives accumulated and absorbed across half a century. Cross-disciplinary theoretical and conceptual research represents a significant opportunity for the marketing discipline to reach past present boundaries of business application and address quickly moving business problems (Moorman et al. 2019). In the next essay, Terry Clark examines the issue of disciplinary decline in terms of its narrowing horizons. 


\section{Finessing our way to irrelevance}

\section{Terry Clark}

On both the academic and practitioner sides of the discipline, marketing is in trouble. Even those who do not believe this to be true often let slip hints that they too have doubts. For example, the authors of a recent article aimed at demonstrating marketing's central importance to the firm confess that,

“....since the early 1980s, hundreds of studies have investigated the impact of various aspects of firms' marketing on performance outcomes...to date, the findings remain fragmented and inconclusive." (Katsikeas et al. 2016, p. 1).

Among other things, this observation reveals that as late as 2016, the purported health and influence of Marketing was far from clear.

Similarly, in a paper ostensibly making the point that Marketing drives stock price (presumably, a key indicator of the discipline's health), Kumar and Shah (2011) preface their arguments with a lament that traditional,

“...marketing practices are increasingly viewed with skepticism. In many organizations, marketers struggle to document the return on investment for marketing expenditures; as a result, the marketing function is poorly aligned with the strategic goals of the company, marketing has less influence in the boardroom -and the marketing budget allocation is viewed as a questionable cost rather than a worthy investment." (p. 24).

Here too, authors who are making a case for the robust health of the discipline begin by tacitly capitulating to the notion that marketing is indeed in trouble.

In the interests of exploring the point directly, this brief note starts by assuming that marketing is in trouble. Certainly, there are sufficient eminent scholars inside the field (albeit a minority) for us to examine the issue and to venture thoughtful conjectures as to why this might be the case. Accordingly, we explore three possible avenues of inquiry: 1) Marketing's illusions of well-structured problems; 2) Marketing's illusions of technique (or method); and 3) the essentially reflexive nature of Marketing's task. These three lines of inquiry have been selected for their face validity in shedding light on the health of our discipline. In combination, these three collude (as it were), to produce a paradoxical situation, in which while a field develops greater and greater, it simultaneously becomes more marginalized. In other words, the question becomes, are we finessing our way to irrelevance?
Illusions of well-structured problems

A problem is said to be well-structured if it has the following characteristics: 1) well-defined initial and goal states; 2) the initial and goal states are connected by sets of legitimate steps or criteria; and 3) algorithms and procedures exist to apply the legal steps to produce a solution (Simon 1973). A wellstructured problem always produces a 'right' answer when the correct algorithm is applied. For example, converting a Fahrenheit temperature into Celsius; inverting a mathematical matrix; and calculating the trajectory of an object's flight path, are all examples of well-structured problems, because they all easily meet the three criterial set out above. In all cases, the problem is easily solved because it is well-structured. It is our contention that not many well-structured problems in marketing are particularly interesting.

Conversely, in the case of ill-structured problems: 1) the initial and/or goal states are ill-defined; 2) criteria connecting initial and goal states are unclear and/or unknown; and 3) no agreed upon algorithms or procedures exist to produce a 'correct' solution. Indeed, it is impossible to produce a 'correct' solution to an illstructured problem. However, because of the criteria set out above, it is possible that an ill-structured problem will have many possible acceptable alternate but very different solutions. For example, solving the problem of plastic pollution in the oceans, addressing childhood obesity, and lowering the level of political rhetoric, are all ill-structured problems because none of them begin with clear (or clearly agreed upon) initial states, neither are there agreed upon solution states, and no commonly accepted algorithms or procedures to move the problem from its initial to goal state exist.

To bring the issues closer to marketing, consider that such typical problems as: how much to spend on advertising, how to develop a strong brand, and which brand spokesperson would be best, are problems that reasonable people will disagree on defining and analyzing, and that they will undoubtedly produce very different but nevertheless acceptable solutions. These typical marketing problems are ill-structured because:

Initial states are ambiguous Virtually all-important marketing problems may be viewed from multiple points of view (society, the firm, the marketing manager, the CFO, customers, competitors, etc.): therefore, reasonable participants will differ in their understanding of the nature of the problem.

\section{Goal states are ambiguous}

The objective function for most marketing problems is conjectural and subjective, and reasonable observers will differ on what the goal is (should be) at any given time. 
Multiple conflicting algorithms exist that may be applied to produce differing, perhaps contradictory solutions: there is no reason to suppose this state of affairs will ever be otherwise.

Thus, our first conjecture regarding the troubled state of marketing is that while the field consist largely of illstructured problems, its academic members behave as if it is faced with largely well-structured problems. This state of affairs is exacerbated by the fact that marketing has specialized in developing methods used to solve well-structured problems.

\section{Marketing's illusions of technique (or method)}

When a field believes its subject matter is largely well-structured, it will quite reasonably develop appropriately exacting methods and algorithms to solve the well-structured problems at hand. Such refined exactitude increases confidence in solving well-structured problems. However, if after having developed sophisticated methods to solve well-structured problems, the field then applies them to solve ill-structured problems, a sort of myopia or illusion sets in.

According to Clark et al. (2014), when methodological sophistication takes precedence in producing solutions to a field's larger substantive (i.e. ill-structured) issues, a culture that increasingly demands even more highly developed methodological refinements emerges. Accelerating methodological expectations point researchers towards well-structured phenomena, which can only be found at micro levels of analysis, while scholarship attempting to address the larger illstructured problems is frowned upon.

A tacit acknowledgement of this problem appeared in a recent Marketing Science editorial, introducing the journal's "Science-to-Practice Initiative," in which the authors concede that.

"...sometimes the diffusion of insights and methods from [academic Marketing Science]...to the real world is limited...As our field becomes more technically complex, this... process faces even higher hurdles... as a field, we continue to develop many more scientific insights and operational models than get used." (Desai et al. 2012, p. 1).

This sentiment seems to be shared by Ford (2004), who concedes that the "...big problem with management science models is that managers practically never use them" (Little 1970, p. B 466).

The issue is that practicing managers grapple with ill-structured, messy problems, while academic marketing produces increasingly sophisticated methods suitable for solving wellstructured problems. According to Clark et al. (2014) despite "...methodologies as sophisticated as any in the social sciences...academic marketing is the least influential of the mainstream academic business disciplines" (p. 223). This mismatch, of applying methods best suited to well-structured micro-level problems, to large, unwieldy ill-structured problems, is a second conjecture as to why academic marketing is becoming increasingly marginalized. However, the situation is further exacerbated when the dynamic issue of reflexivity is introduced.

\section{The reflexive nature of our task}

Not only are marketing phenomena ill-structured, and therefore not easily amenable to precise and sophisticated measurement and micro-analysis, but they are also fundamentally reflexive in nature. Giddens (1987) describes reflexivity in the following terms:

“...theories, concepts and findings of social science, or versions of them, are routinely drawn back into the social environments they analyze...[the]....more interesting, significant or 'explanatory' a set of ideas in social science is, the more likely it is to be taken over by lay agents and to enter constitutively into their conduct." (p. 197).

In other words, for example, the difference between studying the stars and studying marketing channel managerial behavior, is that the stars cannot react to and are not changed by research conducted on stars, nor by any published findings. However, the marketing scholar who observes, measures, and analyzes managerial behavior in channels of distribution, will likely publish their findings. Those findings in turn, will likely be read by the very phenomena studied - managers in the channel of distribution. Having read the findings, the managers will likely learn/react/respond to them and change their behaviors accordingly. Therefore, the thing studied (managers) is changed by the very fact of being studied. This is the essence of reflexivity. On the other hand, the astronomer who studies the stars, gathers data, analyzes it and publishes their findings is not likely to have any effect on the stars they study.

Marketing phenomena are fundamentally reflexive. This reflexivity is evident at three different levels: between academic researchers and practitioners; between practitioners and consumers; and between academic researchers and consumers. In each case, an iterative relationship exists such that the parties end up influencing and changing one another. In other words, marketing phenomena is intrinsically dynamic and evolving.

Key in each case is the fact that marketing participants are observing, evaluating, analyzing, theorizing, learning from one another, and then changing their behavior, such that marketing phenomena cannot remain static. Most tellingly, for marketing scholars, to the degree their findings are published, read, and absorbed by the practitioners and consumers they 
study, their very findings will change the objects they have studied, and thus, over time, the findings will no longer reflect the state of nature initially observed. Thus, a large, complex and vastly ill-structured dynamic system emerges, in an endlessly iterative evolution. The wholesale neglect of this phenomena, which affects every area of marketing, is our third conjecture on why academic marketing tends to be marginalized and uninfluential.

\section{Concluding thoughts}

Confounding the ill-structured nature of marketing phenomena with well-structured micro-problems, the development of a methodological apparatus finely tuned to the solution of well-structured problems, and a disciplinary blindness to the reflexive nature of the field's subject matter, even at face value, deserve further attention to understand their likely dysfunctional effects on the field. Unless and until these issues are acknowledged, understood and addressed, the situation described by Webster (2005) is likely to continue:

"There is evidence that marketing has lost its importance and relevance as a management function in many companies.... Today [management strategy research]...is a literature more widely read and valued by managers than the marketing literature, evidenced by the large numbers of management subscribers compared with those of marketing journals." (pp. 121-122).

Perhaps more chillingly, the discipline will continue losing influence within the confines of its own highly refined and isolated scholarly bubble, where we give one another comfort by "...mostly talking to ourselves..." (Reibstein et al. 2009, p. 3).

Increased methodological finesse will not get marketing out of its existential impasse. What is needed is better indigenous marketing theory (Hunt 2020). A discipline-wide return to theory that addresses marketing relevant problems can help illumine the situation and lead us to a healthier, more appropriate intellectual space amid the family of disciplines. Theory and conceptual work serve as the organizing framework used to make sense of and to explain (Stewart and Zinkhan 2006; Varadarajan 2017; Yadav 2018). Only when we have a renewed and adequate body of theory will the secondary work of empirical exploration and verification be useful. Identifying disciplinary roadblocks to innovative theoretical inquiry is the first step. The next essay explores the issue that marketing scholars and practitioners alike continue to grapple with.

\section{Marketing's perception problem}

\section{David Stewart}

Marketing, as a discipline, has a perception problem, but I am very positive about marketing's real and potential contributions to the customer, the firm, and society at large. Let me begin with the perceptual problem and will do so with an anecdote to give a sense of the problem. I live and work in California and spend a considerable amount of time talking with high-tech managers about hiring marketing graduates. While these are always polite conversations, they often end with some variation of "We don't hire marketing students, we hire engineers, and if they're not good at engineering, we'll put them in marketing." There is a grudging recognition of the need for marketing in such statements, but they do not reflect an admiration for the intellect, skills, creativity, or strategic thinking of people who perform the marketing function. Lest this be dismissed as just an isolated anecdote, it is useful to note that individuals with a background in marketing make up less than $3 \%$ of the board members of the 1500 Standard \& Poors firms (Whitler et al. 2018). A primary reason for this is the perception that marketing is tactical and lacks strategic vision (Whitler 2016).

One reason for such perceptions is that the way marketing is manifest in organizations is often quite different from organization to organization and quite different from what we teach as marketing in our university curriculum. There is certainly ample evidence that marketing takes many forms across organizations.

In an effort to better understand what marketing does for organizations and also to identify different types of marketing organizations the Association of National Advertisers in the United States, in collaboration with Booz Allen, surveyed marketing organizations to determine what was expected of them and how their role was defined within the organization. This survey revealed six very distinct types of marketing organizations based on how the role of marketing was defined in the larger corporation: (1) Growth Champion, (2) Senior Counselor, (3) Brand Foreman, (4) Growth Facilitator, (5) Best Practices Advisor and (6) Service Provider (Landry et al. 2005). A similar study (Slater and Olson 2001) found four types of marketing organizations: Aggressive Marketers, Mass Marketers, Marketing Minimizers, and Value Marketers, which interacted with characteristics of the firm's strategy, as determined using the Miles and Snow (1978) typology of business strategy, to produce different performance outcomes (see also, Olson et al. 2005).

These different types of marketers and marketing organizations are defined by the objectives and expectations associated with the marketing organization. In these studies, the role of marketing varies from tactical, e.g., sales support, 
developing collateral materials, developing retail advertising, to strategic, e.g., finding new growth opportunities and driving development of these opportunities. The scope of marketing can be narrow, e.g., managing a brand to very broad, e.g., growing the entire organization. And, the role of marketing can be that of line management, e.g., driving growth, managing brands or that of staff, e.g., counselor or keeper of best practices. Clearly, the role(s) and function(s) of marketing are not uniform. But this is only part of the problem.

There is convincing evidence that the influence of marketing as a business function and academic discipline has been declining over time (Verhoef and Leeflang 2009; Reibstein et al. 2009; Fournaise Marketing Group 2011; Nath and Mahajan 2011a, 2011b; Webster and Lusch 2013; Homburg et al. 2015; Clark et al. 2014). Part of this decline is due to the ambiguous definition of marketing in practice; part of it is due to marketing's success in diffusing its customer-centric perspective throughout organizations with a loss of identity as the source and keeper of this perspective; part of it is due to marketing's ceding important functions and tasks to other disciplines as it has sought legitimacy as a social science while distancing itself from its historical role in such practical tasks as distribution, sales and selling, and revenue management. But the reality is that marketing has always had a respect problem and some of contemporary marketing's problems of definition arise from its efforts to overcome this centuries old problem (Winsor and Stewart 2018).

The academic studies documenting the decline of marketing's influence span numerous countries where marketing has existed as a business function for decades. However, such empirical studies are not the only evidence of a decline in marketing's influence. Five of the ten largest advertising agency companies are associated with accounting/consulting firms and/or information technology companies (Accenture's Accenture Interactive, PwC's PwC Digital Services, Deloitte's Deloitte Digital, Cognizant's Cognizant Interactive, IBM Corp.'s IBM iX) (Ad Age 2018). These consulting and IT companies are growing while traditional advertising agencies are flat or declining. There is also a growing trend toward eliminating CMO positions (Handley 2019; Schultz 2019). On the academic side of the discipline, marketing has a long history of borrowing theories and methods from other disciplines, but other disciplines cite little of the marketing literature (Pieters and Baumgartner 2002; Clark et al. 2014; Wu et al. 2017).

At a broader, conceptual level, marketing, as a discipline, has sought to define itself as a social science (rather than a business discipline) at a time when academic social sciences are being roundly criticized and the best "science" is being carried out by business. The diminishing credibility of academic social sciences and well documented failures to replicate key empirical findings raise serious concerns about the validity of much academic social science (The
Reproducibility Project, Open Science Collaboration 2015). In contrast, there is increasing use of social science in business, where the discipline of a profit motive creates incentives for replication (Schrage 2015).

Aristotle (1274) had only criticism for those he branded as useless profiteering parasites. The merchant classes in China and in Japan were viewed as greedy and immoral (BarbieriLow and Yates 2015; Fairbank and Goldman 2006). They were viewed as producing nothing of value and of profiting from others. Shopkeepers in the Middle Ages were prohibited from enticing customers into their shops with food, drink or signage, or engaging in things like sampling (Winsor and Stewart 2018). Thomas Aquinas (1274), quoting another scholar, said, "He who in trading sells a thing for more than they paid for it, must have paid for it less than it was worth, or must be selling it for more than it is." This is an interesting view of value that leaves little room for the legitimacy of marketing. And, it is here that we see the real perceptual problem confronted by marketing.

The marketing literature is filled with discussions of "value", but there is considerable improvement that can be added to its various applications (see Payne et al. 2017 for a recent discussion). There is considerable work in our discipline that emphasizes value as defined by the customer. This is fine, but it fails to differentiate real value for the customer from artificial perceptions of value created by manipulative "marketing" tactics and outright deception. Indeed, as a discipline, marketing has been strangely silent about the value it adds (rather like admitting to the criticism of Aquinas). For example, exchange is often a part of the definition of marketing yet marketing often fails to make a strong case that exchange is not always or even occasionally, zero sum. A zero-sum view of exchange suggests that one party's gain is the other party's loss, and this leaves no room for any value added by an intermediary. Within such a perspective, any cost related to the intermediary must be subtracted from whatever value is received by the buyer and/or seller. Under a zero-game perspective, the buyer, seller, or both are already losers, so the intermediary is both a facilitator of loss of value by the parties to the exchange and an undeserving recipient of a portion of the value exchanged. This is a mischaracterization of market exchange.

In the vast majority of exchanges, there is value on all sides: the producer is able to sell above its costs, the buyer is able to obtain a product or service that is valuable at a lower cost than they could produce it themselves, and intermediaries add value by facilitating a valuable multi-party-exchange that would otherwise have not occurred and, often, by adding further value during the exchange process, such as product enhancement, service(s), and risk reduction (for both buyer and seller).

Despite our focus as a discipline on a customer definition of value, we remain trapped in a producer concept of value when defining our role. There remains a focus on cost or the labor that goes into the creation of value, rather than the 
thought that goes in the creation of value. There is a focus on production as opposed to the innovation, creativity, or thinking that is the essence of a product or service. Stated somewhat differently, there is a focus on the tangible, rather than the intangible.

The focus on the tangible is institutionalized in the standards and practices of financial accounting. Few intangible assets, most especially those created by the firm rather than those purchased, appear on the balance sheet. Such assets as brand, customer loyalty, and relationships with suppliers, distributors and customers, all sources of value created by marketing, go unrecognized on the balance sheet and income statement. This has always been problematic from a financial reporting perspective and certainly makes the contribution of marketing difficult to explicitly identify. However, this absence of reporting has become especially problematic in recent years.

In the 1970 's and 80 's, more than $80 \%$ of the value of firms, at least as it was recorded at the time, resided in tangible assets - buildings, equipment, and inventory. Today, more than $80 \%$ of the value of firms rests in intangible assets (Ocean Tomo 2015). It is ironic that at a time when the intangible assets that marketing creates and manages are so large, marketing as a discipline has experienced a decline in influence. While it is tempting to blame the accountants, the real problem is that marketing has done a poor job of explaining how it contributes to the creation of value and of quantifying this value in financial terms (Webster 1981).

Marketing's value has always been in the intangible. Even when moving goods, distribution, the movement is actually intangible. It is the physical good, or physical elements of the good or service, that goes from one place to another, but what happens in between and is this a source of value? Conveniently matching supply and demand, especially in the presence of heterogeneous demand most certainly adds value. Intangible elements of products and services, brand, customer experience, and relationships all can, and often do add value, even if these things are not readily visible in physical form.

At their most fundamental level, intangible assets are about people and relationships - what people know, who people trust, brands, a source of identity for both seller and buyer, experiences, convenience, and accessibility. These are all things for which marketing has enormous expertise and executes well. These intangible assets add value, but the world continues to behave as though tangible assets are the dominant sources of value.

The problem, of course, is that the value of intangible assets is often uncertain and of unknown duration. These are reasons accountants are reluctant to put them on the books. But the reality is that uncertainty and an unknown duration of value also apply to tangible assets. In reality, any asset, tangible or intangible, is only as valuable as the way it is managed. The financial value of a tangible asset is often linked to an on-going market that provides a benchmark for value. Thus, a building's value is determined by benchmarking against recent sales of similar buildings. But this is just a convenient convention.

A building is not inherently an asset. It is only an asset if it can be used to make money. A vacant building is not an asset; it is a liability. Similarly, a brand has value as an asset only when it facilitates making money. The problem is that there are not on-going markets for brands, and especially for comparable brands, that can be used to benchmark. Current accounting practices perpetuate the fiction that something is an asset absent the way it is managed. It is also the case that the value of an intangible asset is more sensitive to the way it is managed because it is often difficult to separate the asset from other factors and institutions that increase the value of an asset, such as a brand (Haskel and Westlake 2018). Thus, Disney was able to dramatically increase the value of Marvel and its thousands of characters because the characters have much more value as film characters than as characters in comic books.

The problem in marketing is that we do a poor job of explaining how intangible assets create present and future value in financial terms. The people who do capital budgeting in finance are always making assumptions about the future. If building a factory, what is its value over time? What cash flows will the building produce over five years or over ten years? Will such future cash flows justify the investment in the building? Undergirding the seeming hard numbers that are offered as answers to such questions are numerous assumptions and uncertainties that are similar to assumptions related to the value of an intangible asset, such as a brand. The obstacle is that marketing simply doesn't speak the language of the firm, and that is the language of finance. A point echoed in Brown et al. (2005), "marketing managers are not finance literate and have trouble answering [budgeting] questions" (p. 11).

We could also do a much better job explaining our contributions to society, and marketing does many things that are really important for society (see Wilkie and Moore 1999). We improve the quality of life; we save lives. Marketers and marketing simply do not articulate these contributions often or well. The reality is that marketing arose as a discipline to solve a very important societal problem. That problem was to get goods and services from one place to another. As people left the farm and society became more urbanized, there was an increasing distance between buyers and sellers. The discipline then evolved to focus on a better match of supply with the demand in markets characterized by heterogeneity arising from an increasingly affluent and diverse marketplace. Marketing's roots are really in analyzing and serving market demand and demand heterogeneity and creating and optimizing the valuable resources necessary for creating a diverse supply of goods and services with the needs of differing segments of customers.

Marketing needs to return to these roots, tell its story, and translate what it does into financial terms. If it were to do so, 
there are numerous sets of issues it could address that would help demonstrate its relevance. There are issues of governance, ethics, and innovation that are inherent in the problems that the marketing discipline originally arose to address: issues related to how to organize a value delivery system. There are also issues around morality and sustainability and about performing better, faster, and more efficiently, while improving the quality of life. Marketing does not really tell the intangible story very well. We talk about brands, how people feel, and the characteristics of the customer. All are important topics but not very compelling without an explicit link to the value of the firm and society at large.

\section{Concluding thoughts}

Marketing suffers from the perception that it does not address issues that are conceptually relevant to a firm, that is, it has very little to say about how firms create value as measured by financial results. The contributions of marketing to the creation and management of intangible assets such as brand, customer equity, and relationships with distributors, among others, are not generally reflected on the balance sheet or any financial reporting, despite the fact that such assets represent a sizeable portion of the value of firms. If marketing is to be relevant to the firm there must be a focus of scholarship on marketing's contribution to the financial performance of the firm including the unique issues associated with creating, managing, and measuring the value of intangible assets and the development of aids for practicing marketing managers who need to justify their expenditures and efforts in terms of financial outcomes.

\section{Forward looking}

In this collection of essays, we consider a number of issues related to the marginalization and declining influence of marketing and the opportunities our discipline has to contribute to the state of our scholarship through innovative theoretical exploration and relevant, timely value for practice. Collectively, these essays bring to light critiques meant to shed light on a myopic drift of the field and failure to move as quickly as the external business environment (Moorman et al. 2019). As used in the essays, the term myopic drift suggests that Marketing has moved slowly, imperceptibly, unguided, and dysfunctionally in unwanted and increasingly narrowed directions. This drift includes the contracting of topical expertise, the loss of traditional marketing domains to other

\footnotetext{
${ }^{1}$ The authors are aware of a number of special issues and calls for work in these areas; however, one of our driving critiques is that we have moved slowly in areas of emerging phenomena (Yadav 2018) and such calls are relatively recent compared to extant technological and customer data related issues.
}

business functions, and an increasingly less managerially relevant research program. Embedded within this myopic drift is significant lag in the recognition to provide what Hunt (2020) refers to as indigenous marketing theorizing that is relevant to real business problems. The lack of indigenous marketing theory related to business problems steeped in technology and customer data ${ }^{1}$ represent our discipline's response for what kinds of research are considered worthy and relevant for theoretical and conceptual exploration. While the field may continue its drift, this is by no means an inevitable future. Honest, thoughtful reflection, wide-ranging discussion, timely re-appraisals, and careful course corrections are necessary steps for the field to regain its health, vigor, and relevance going into the future. Certainly, the degree to which the field produces wide-ranging and significant contributions to scholarship, practice, public policy, and to society, drift will diminish.

One area that can and should be addressed with great urgency is increasing the comprehensibility of our journals to practitioners and a wider array of stakeholders (MacInnis et al. 2020). It is no secret to marketing scholars that our work is often ill-suited for most practitioners. As such, it constitutes a dead-weight loss. The Marketing Science editorial accompanying the journal's Science-to-Practice initiative (Desai et al. 2012) says as much.

However, simply "translating" our technical articles into practitioner pieces in "practitioner language" would serve only to entrench our culture in mindsets and methods that created the divide in the first place, further insulating the field from important presumed audiences. As MacInnis et al. (2020, p. 1) put it, "....we have handicapped ourselves by adhering to a set of implicit boundaries or defaults about what we study, why we should study it, and how we communicate the significance of our work." This reinforces that marketing researchers have a responsibility to ask better questions, create more meaningful frameworks and conceptual theorizing about problems that matter, both to the academic community, as well as practitioners. This can serve as an intellectual course correction to bring meaningful and well-guided research back to the forefront of marketing-appropriate theoretical and conceptual development.

Rather than creating parallel journal universes (jargon-academic and translated-practitioner) we should learn from our friends in neighboring disciplines, particularly Management, who have achieved a remarkable balance between rigor and relevance, such that academics maintain journals of the highest academic standing, without alienating practitioners with impenetrable language. Such fundamental changes can only be achieved by a radical alteration to journal and doctoral orientation policies (Yadav 2010). However, the beauty of these approaches is that they can be achieved coup-de-main by a handful of influential players. Efforts such as the recent AMS Review (see Vargo and Koskela-Huotari 2020) special 
issue for advancing conceptual and theoretical articles in marketing is a step in the right direction, which serves to create the necessary foundation for new conversations around how our discipline addresses change and redirection.

Thus, the discipline finds itself in a particularly researchtarget-rich environment at present. Provided it can do so in a manner accessible to pertinent stakeholders, the field is wellplaced to engage in the theoretical development and empirical exploration of areas such as cybersecurity, data privacy, artificial intelligence / machine learning, and data security to name only a few (e.g. Martin and Murphy 2017; Martin et al. 2017; Martin 2018). Certainly, customer data privacy and security should be a central area of development given marketing's key role as collection agent, data steward, and communicator in this evolving value exchange space (Morey et al. 2015). The scale of digital integration in a big data world only increases the seriousness and extent of customer data breaches and the need for marketers to be positioned as customer security advocates and ambassadors for societal well-being. The evolving (and contested) space at the interface of the technical and decision-making sides of data analytics and cybersecurity are ripe for marketing incursions. So too, are areas of current and lost expertise that the 2020 COVID-19 pandemic has revealed in such areas as honest and authentic content marketing, social marketing, and supply chain. Mass misinformation, fake news, and predatory content marketing practices are more prevalent in times of public crisis and the need to understand such environments and promote public health and awareness are very important. There are no doubt other important new interfaces marketing can contribute to; the emphasis is highly likely to remain complex in nature and will require new development in our theories and frameworks.

\section{Conclusion}

The overall objective of the scholarly essays in this paper is to identify key issues for rethinking the current state of the discipline of marketing. The authors were given the freedom to select a specific area or purpose of marketing that they thought should be addressed and discussed. All of the essays started with a foundation of historical facts and attempted to identify how there could be some disruption in thought or debate about the current path of knowledge development. Throughout the collection a key emphasis on a disciplinewide drift and myopic approach to what constitutes valuable contribution was revealed. All disciplines need periodic reflection and self-assessment. The ultimate goal is to have other scholars' critique, challenge, or add more support for our positions. In this way we can advance and have a positive impact on the field of marketing.

\section{References}

Ad Age (2018), Ad Age agency report, (Chicago: Crain Communications).

Alderson, W. (1937). A marketing view of competition. Journal of Marketing, 1(3), 189-190.

Alderson, W. (1957). Marketing behavior and executive action. Homewood: Richard D. Irwin, Inc..

Alter, A. (2017). Irresistible: The rise of addictive technology and the business of keeping us hooked. New York, NY: Penguin Random House.

Aquinas, St. T. (1274). Summa Theologica, Question LXXVII, Article 4, Dominican Translation, Vol. VIII. 130.

Bagozzi, R. P. (2018). Three systems underpinning marketing behavior. AMS Review, 8(1-2), 23-29.

Barbieri-Low, A. J., \& Yates, R. D. S. (2015). Law, State, and Society in Early Imperial China: A Study with Critical Edition and Translation of the Legal Texts from Zhangjiashan Tomb No. 247. Boston: Brill academic publishers.

Barney, J. B. (2020). Contributing to theory: Opportunities and challenges. AMS Review. https://doi.org/10.1007/s13162-020-00163-y.

Berthon, P., Hulbert, J. M., \& Pitt, L. F. (1999). To serve or create? Strategic orientations toward customers and innovation. California Management Review, 42(1), 37-58.

Berthon, P., Pitt, L. F., \& Campbell, C. (2019). Addictive de-vices: A public policy analysis of sources and solutions to digital addiction. Journal of Public Policy \& Marketing, 38(4), 451-468.

Brown, S. W., Webster, F. E., Steenkamp, J. B. E. M., Wilkie, W. L., Sheth, J. N., Sisodia, R. S., Kerin, R. A., MacInnis, D. J., McAlister, L., Raju, J. S., Bauerly, R. J., Johnson, D. T., Singh, M., \& Staelin, R. (2005). Marketing renaissance: Opportunities and imperatives for improving marketing thought, practice, and infrastructure. Journal of Marketing, 69(4), 1-25.

Clark, T., Key, T. M., Hodis, M., \& Rajaratnam, D. (2014). The intellectual ecology of mainstream marketing research: An inquiry into the place of Marketing in the Family of business disciplines. Journal of the Academy of Marketing Sciences, 42(3), 223-241.

Cox, R. (1961). How mature is our marketing philosophy? In M. Bell (Ed.), Marketing: A maturing discipline (pp. 123-133). Chicago: American Marketing Association.

Desai, P. S., Bell, D., Lilien, G., \& Soberman, D. (2012). The science-topractice initiative: Getting new marketing science thinking into the real world. Marketing Science, 31(1), 1-3.

Diamond, J. (2002). Evolution, consequences and future of plant and animal domestication. Nature, 418(6898), 700-707.

Diamond, J. M. (2010). The worst mistake in the history of the human race. Oplopanax Publishing.

Eisend, M. (2015). Have we progressed marketing knowledge? A metameta-analysis of effect sizes in marketing research. Journal of Marketing, 79(3), 23-40.

El-Ansary, A., Shaw, E. H., \& Lazer, W. (2017). Marketing's identity crisis: Insights from the history of marketing thought. AMS Review, $8(1-2), 5-17$.

Fairbank, J. K., \& Goldman, M. (2006). China: A New History (2 ${ }^{\text {nd }}$ enlarged ed.). Cambridge: Belknap Press, and Imprint of Harvard University Press.

Feng, H., Morgan, N. A., \& Rego, L. L. (2015). Marketing department power and firm performance. Journal of Marketing, 79(5), 1-20.

Ferrell, O. C. (2018). Marketing's identity crisis: it's complicated. AMS Review, 8(1-2), 30-38.

Ferrell, O. C., Hair, J. F., Marshall, G. W., \& Tamilia, R. D. (2015). Understanding the history of marketing education to improve classroom instruction. Marketing Education Review, 25(2), 159-175.

Fournaise Marketing Group. (2011). 73\% of CEOs Think Marketers Lack Business Credibility: They Can't Prove They Generate Business 
Growth. Retrieved from https://www.fournaisegroup.com/ marketers-lack-credibility/.

Frazier, G. L. (2011). From the incoming editor. Journal of Marketing, $75(4), 1-2$.

Gatignon, H., Lecocq, X., Pauwels, K., \& Sorescu, A. (2017). A marketing perspective on business models. AMS Review, 7(3-4), 85-89.

Giddens, A. (1987). Social theory and modern sociology. Cambridge: Polity Press.

Gupta, S., Lehmann, D. R., \& Stuart, J. A. (2004). Valuing customers. Journal of Marketing Research, 41(1), 7-18.

Handley, L. (2019), "Marketing Chiefs Face a 'Final Desperate Fight for Survival' in 2020, Says Report," CNBC, Oct. 29, https://www.cnbc. com/2019/10/29/marketing-trends-chief-marketers-face-a-finalfight-for-survival.html

Harari, Y. (2014). Sapiens: A brief history of humankind. New York: Random House.

Haskel, J., \& Westlake, S. (2018). Capitalism without capital: The rise of the intangible economy. Princeton: Princeton University Press.

Homburg, C., Workman, J. P., \& Krohmer, H. (1999). Marketing's influence within the firm. Journal of Marketing, 63(2), 1-17.

Homburg, C., Vomberg, A., Enke, M., \& Grimm, P. H. (2015). The loss of the marketing Department's influence: Is it really happening? And why worry? Journal of the Academy of Marketing Science, 43(1), 1-13.

Houdek, P. (2017). Puppet master: Possible influence of the parasite toxoplasma gondii on managers and employees. Academy of Management Perspectives, 31(1), 63-81.

Houston, M. (2016). Is 'strategy' a dirty word? Academy of Marketing Science, 44(5), 557-561.

Howard, J. A. (1983). Marketing theory of the firm. Journal of Marketing, 47(4), 90-100.

Hunt, S. D. (1991). Modern marketing theory: Critical issues in the philosophy of marketing science. Nashville: South-Western Publishing.

Hunt, S. D. (2018). Advancing marketing strategy in the marketing discipline and beyond: From promise, to neglect, to prominence, to fragment (to promise?). Journal of Marketing Management, 34(12), 16-51.

Hunt, S. D. (2020). Indigenous theory development in marketing: The foundational premises approach. AMS Review. https://doi.org/10. 1007/s13162-020-00165-w.

Katsikeas, C. S., Morgan, N. A., Leonidas, C., \& Hult, T. M. (2016). Assessing performance outcomes in marketing. Journal of Marketing, 80(2), 1-20.

Key, Thomas M. (2017). Domains of digital marketing channels in the sharing economy. Journal of Marketing Channels, 24 (1-2), 27-38.

Kohli, A. K. (2009). From the editor. Journal of Marketing, 73(1), 1-2.

Kotler, P. (2018). Why broadened marketing has enriched marketing. AMS Review, 8(1-2), 20-22.

Kumar, V. (2015). Evolution of marketing as a discipline: What has happened and what to look out for. Journal of Marketing, 79(1), $1-9$

Kumar, V., \& Shah, D. (2009). Expanding the role of marketing: From customer equity to market capitalization. Journal of Marketing, 73(6), 119-136.

Kumar, V., \& Shah, D. (2011). Can marketing lift stock prices? MIT Sloan Management Review, 54(4), 24-26.

Kumar, V., Mittal, V., \& Morgan, N. (2018). Reflections on publishing in the journal of marketing. Journal of Marketing, 82(6), 1-9.

Landry, E., Tipping, A., \& Dixon, B. (2005). Six types of marketing organizations: Where do you fit in?. Strategy + business. Retrieved from https://www.strategy-business.com/article/rr00025? gko=489ba.

Little, J. D. C. (1970). Models and managers: The concept of a decision calculus. Management Science, 16(8), B-466-B-485.
MacInnis, D. J., Morwitz, V. G., Botti, S., Hoffman, D. L., Kozinetz, R. V., Lehmann, D. R., Lynch, J. G., \& Pechmann, C. (2020). Creating boundary-breaking, marketing-relevant consumer research. Journal of Marketing, 84(2), 1-23.

Martin, K. (2018). The penalty for privacy violations: How privacy violations impact trust online. Journal of Business Research, 82(1), $103-116$.

Martin, K. D., \& Murphy, P. E. (2017). The role of data privacy in marketing. Journal of the Academy of Marketing Sciences, 45(2), $135-155$.

Martin, K. D., Borah, A., \& Palmatier, R. W. (2017). Data privacy: Effects on customer and firm performance. Journal of Marketing, 81(1), 36-58.

McAlister, L. (2016). Rigor versus method imperialism. Journal of the Academy of Marketing Science, 44(5), 565-567.

Miles, R. E., \& Snow, C. C. (1978). Organizational strategy, structure, and process. Stanford: Stanford University Press.

Moalem, S. (2007). Survival of the sickest. In Survival of the sickest: The surprising connections between disease and longevity. New York: HarperCollins.

Moorman, C., van Heerde, H. J., Moreau, C. P., \& Palmatier, R. W. (2019). Challenging the boundaries of marketing. Journal of Marketing, 83(5), 1-4.

Morey, T., Forbath, T., \& Schoop, A. (2015). Customer data: Designing for transparency and trust. Harvard Business Review, 93(5), 96105.

Nath, P., \& Mahajan, V. (2008). Chief marketing officers: A study of their presence in firms' top management teams. Journal of Marketing, 72, 65-81.

Nath, P., \& Mahajan, V. (2011a). Marketing in the C-suite: A study of chief marketing office power in firms' top management teams. Journal of Marketing, 75(1), 60-77.

Nath, P., \& Mahajan, V. (2011b). Marketing in the C-suite: A study of chief marketing officer power in firms' top management teams. Journal of Marketing, 75(1), 60-77.

Ocean Tomo, LLC. (2015). Annual Study of Intangible Asset Market Value from Ocean Tomo, LLC. Retrieved from: http://www. oceantomo.com//2015/03/04/2015-intangible-asset-market-valuestudy/

Olson, E., Slater, S. F., \& Tomas Hult, G. (2005). The performance implications of fit among business strategy, marketing organization structure, and strategic behavior. Journal of Marketing, 69(3), 4965.

Payne, A., Frow, P., \& Eggert, A. (2017). The customer value proposition: Evolution, development, and application in marketing. Journal of the Academy of Marketing Science, 45(4), 467-489. https://doi. org/10.1007/s11747-017-0523-z.

Pieters, R., \& Baumgartner, H. (2002). Who talks to whom? Intra- and interdisciplinary communication of economics journals. Journal of Economic Literature, 40(2), 483-509.

Rand, W., Rust, R. T., \& Kim, M. (2018). Complex systems: Marketing's new frontier. AMS Review, 8(3-4), 111-127. https://doi.org/10. 1007/s13162-018-0122-2.

Reibstein, D. J., Day, G., \& Wind, J. (2009). Guest editorial: Is academic marketing losing its way? Journal of Marketing, 73(4), 1-3.

Sawyer, A. G., Laran, J., \& Xu, J. (2008). The readability of marketing journals: Are award-winning articles better written? Journal of Marketing, 72(1), 108-117.

Schrage, M. (2015), "Why the Future of Social Science is with Private Companies," Harvard Business Review, September 01, https://hbr. org/2015/09/why-the-future-of-social-science-is-with-privatecompanies

Schultz, E. J. (2019), "Why More Brands Are Ditching the CMO Position," Ad Age, July 15, https://adage.com/article/cmo-strategy/ why-more-brands-are-ditching-cmo-position/2183166 
Shaw, A. W. (1912). Some problems in market distribution. Quarterly Journal of Economics, 26(4), 703-765.

Sheldon, R., \& Arens, E. (1976). Consumer engineering: A new technique for prosperity. New York: Ayer Publishing.

Simon, H. A. (1973). The structure of ill structured problems. Artificial Intelligence, 4(3-4), 181-201.

Slater, S. F., \& Olson, E. M. (2001). Marketing's contribution to the implementation of business strategy: An empirical analysis. Strategic Management Journal, 22(11), 1055-1067.

Steenkamp, J. E. (2018). The future of the marketing department at business schools. Journal of the Academy of Marketing Science, 46(2), 169-172.

Stewart, D. W., \& Zinkhan, G. M. (2006). Enhancing marketing theory in academic research. Journal of the Academy of Marketing Science, 34(4), 477-480.

Tadajewski, M. (2014). Paradigm debates and marketing theory, thought and practice. Journal of Historical Research in Marketing, 6(3), 303-330.

Taillard, M., Peters, L. D., Pels, J., \& Mele, C. (2016). The role of shared intentions in the emergence of service ecosystems. Journal of Business Research, 69(8), 2972-2980. https://doi.org/10.1016/j. jbusres.2016.02.030.

Tamilia, R., Ferrell, O. C., \& Hopkins, K. (2020) A historical overview of marketing channels and supply chain networks, Springer Briefs, Springer Nature.

Tellis, G. J. (2017). Interesting and impactful research: On phenomena, theory, and writing. Journal of the Academy of Marketing Science, 45(1), 1-6.

The Reproducibility Project, Open Science Collaboration. (2015). Estimating the Reproducibility of Psychological Science. Science, 349(6251), aac4716-1 - acc4716-8.

Varadarajan, R. (2017). Musings on interesting and impactful theory and research. Journal of the Academy of Marketing Science., 45(1), 10 13.

Varadarajan, R. (2020). Advancing theory in marketing: Insights from conversations in other disciplines. AMS Review. https://doi.org/10. 1007/s13162-020-00167-8.

Vargo, S. L., \& Lusch, R. B. (2008). Why "service"? Journal of the Academy of Marketing Science, 36(1), 25-38.

Vargo, S.L., \& Lusch, R.F. (2016). Institutions and axioms: an extension and update of service-dominant logic. Journal of the Academy of Marketing Science, 44, 5-23. https://doi.org/10.1007/s11747-0150456-3.

Vargo, S. L., Koskeela-Huotari, K., Baron, S., Edvardsson, B., Reynoso, J., \& Colurcio, M. (2017). A systems perspective on markets Toward a research agenda. Journal of Business Research, 79, $260-268$
Vargo, S. L. \& Koskela-Huotari, K. (2020). Advancing conceptual-only articles in marketing. AMS Review, 10, 1-5. https://doi.org/10.1007/ s13162-020-00173-w.

Verhoef, P. C., \& Leeflang, P. S. H. (2009). Understanding the marketing Department's influence within the firm. Journal of Marketing, 73(2), 14-37.

Washington, H. A. (2015). Infectious madness: The surprising science of how we "catch" mental illness. New York: Little, Brown and Company.

Watson, R. T., Pitt, L. F., Berthon, P., \& Zinkhan, G. M. (2002). Ucommerce: Expanding the universe of marketing. Journal of the Academy of Marketing Science, 30(4), 333-347.

Webster, F. E. (1981). Top management's concerns about marketing: Issues for the 1980's. Journal of Marketing, 45(3), 9-16.

Webster, F. E. (2005). A perspective on the evolution of marketing management. Journal of Public Policy \& Marketing, 24(1), 121-126. https://doi.org/10.1509/jppm.24.1.121.63888.

Webster, F. E., \& Lusch, R. F. (2013). Elevating marketing: Marketing is dead! Long live marketing! Journal of the Academy of Marketing Science, 41(4), 389-399.

Whitler, K. A. (2016), Why few marketers are Inv[ted to join boards of directors. Forbes, January 19, https://www.forbes.com/sites/ kimberlywhitler/2016/01/19/why-few-marketers-are-invited-tojoin-boards-of-directors/\#1e1f14ff24a4.

Whitler, K. A., \& Morgan, N. (2017). Why CMOs never last and what to do about it. Harvard Business Review, 95(4), 46-54.

Whitler, K. A., Krause, R., \& Lehmann, D. R. (2018). When and how board members with marketing experience facilitate firm growth. Journal of Marketing, 82(5), 86-105.

Wilkie, W. L., \& Moore, E. S. (1999). Marketing's contributions to society. Journal of Marketing, 63(4), 198-218. https://doi.org/10. $1177 / 00222429990634 \mathrm{~s} 118$.

Winsor, R., \& Stewart, D. W. (2018). The historical roots of Marketing's badge of infamy. In R. Sisodia \& A. Parvatiyar (Eds.), Handbook of advances in Marketing in an era of disruptions - Essays in honor of professor Jagdish Sheth (pp. 64-75). Thousand Oaks: Sage Publications Inc..

Wu, C., Chelsey, H., \& Yan, E. (2017). Disciplinary knowledge diffusion in business research. Journal of Informetrics, 11(2), 655-668.

Yadav, M. S. (2010). The decline of conceptual articles and implications for knowledge development. Journal of Marketing, 74(1), 1-19.

Yadav, M. S. (2018). Making emerging phenomena a research priority. Journal of the Academy of Marketing Science, 46(3), 361-365.

Yadav, M. S. (2020). Reimagining marketing doctoral programs. AMS Review. https://doi.org/10.1007/s13162-020-00169-6.

Publisher's note Springer Nature remains neutral with regard to jurisdictional claims in published maps and institutional affiliations. 